\title{
How large an area of sea do Helgoland seabirds use for foraging during the breeding season?
}

\author{
M. F. Leopold ${ }^{1}$, B. Grunsky ${ }^{2}$, O. Hüppop ${ }^{2}$, A. M. Maul ${ }^{2}$ \\ \& J. van der Meer ${ }^{1}$ \\ ${ }^{1}$ Netherlands Institute for Sea Research; P.O. Box 59, NL-1790 AB Den Burg, Texel, \\ The Netherlands \\ "Inselstation Helgoland des Instituts für Vogelforschung, "Vogelwarte Helgoland"; \\ Postfach 1220, D-27498 Helgoland, Germany
}

\section{INTRODUCTION}

Helgoland has a unique seabird-colony. It is the only site in the German Bight offering rocky ledges that seabirds need for breeding. Food around the colony seems to be plentiful, and the numbers of seabirds have steadily increased during the last decades. Small fish, mainly herring (Clupea harengus), sprat (Sprattus sprattus) and sandeel (Ammodytes spec.) form the staplefood of the birds, but it is unknown where, at sea, the birds find that food (Leopold et al., 1992). This study attempts to answer two questions:

- Where do the birds forage?

- How much do they consume?

\section{METHODS}

From 28th May to 4th June 1991, we counted seabirds from ships in an area of $110 \times 55 \mathrm{~km}$ around Helgoland, following the method described by Tasker et al. (1984). Water-clarity was measured at stations 5 or $10 \mathrm{~km}$ apart, by taking Secchi disk readings. Salinity and water temperature were registered every $10 \mathrm{~min}$. In the colony we monitored: (1) numbers, (2) breeding success and (3) diet of the target species: the guillemot (Uria alge).

\section{RESULTS}

Of the birds seen around Helgoland during the survey, only the common species will be dealt with here. The guillemot, being a poor flyer, restricted its feeding to the vicinity of the colony. All guillemots recorded flying or swimming with fish, were seen within $9 \mathrm{~km}$ from the colony. This small range minimizes energy expenditure of the parents foraging for their chicks, and enables a high breeding success (82\%: Grunsky, 1992). In contrast, the fulmar (Fulmarus glacialis) is an extremely strong flyer. It seeks clear waters to forage on planktonic prey but also uses offal and discarded waste from fishing vessels. 
Its distribution was restricted to the clear waters (Secchi-disk readings were at least $4 \mathrm{~m}$ ) northwest of the island. The highest numbers were associated with two fishing vessels at the edge of our study area. The total number observed at sea exceeded the number of breeders on the island (24 pairs in 1991). We assume these to be mainly nonbreeding subadults (less than 10 years of age) prospecting the colony for future breeding.

Kittiwakes (Rissa tridactyla) preferred the clear water area as well. These good flyers ranged beyond the limits of our study area, as did the fulmars. The kittiwakes took less advantage of the fishing vessels, probably avoiding competition with fulmars and large gulls. Instead, they concentrated in the area where guillemots were plentiful, forming mixed-species flocks. There, the kittiwakes stole fish caught by the guillemots. In addition, they could catch fish driven to the surface by the fishing guillemots.

\section{CONCLUSIONS}

Of the species examined, only the guillemot remained within the study area, while other species ranged much further from the colony to forage. The number of guillemots present at sea was $2943 \pm 222$ birds as calculated by Ordinary Kriging method (van der Meer \& Leopold, in prep.). This corresponds to the number expected from the size of the colony and the attendance patterns of the birds (2889: Grunsky, 1992).

Based on (1) metabolism of adults, (2) cost of egg production, (3) amount of food delivered to chicks, and (4) population parameters according to Grunsky (1992), we calculated the total energy consumption during the breeding season (cf. Cairns et al., 1992). The length of the breeding season was taken from 1st April (10 days before the first egg) to 16th June (mean day of leaving). In total, the guillemots used 1015 million $\mathrm{kJ}$ of energy to complete the 1991 breeding season. The diet (Grunsky, 1992) consisted, for $68.6 \%$, of sandeel $(7.8 \mathrm{~kJ} / \mathrm{g}$ wet mass $)$ and for $31.4 \%$, of clupeoids $(10.8 \mathrm{~kJ} / \mathrm{g})$, so in total 81 tonnes of sandeel and 37 tonnes of clupeoids were needed to support the colony of guillemots.

\section{LITERATURE CITED}

Cairns, D. K., Montevicchi, W. A., Birt-Friesen, V. L. \& Macko, S. A., 1992. Energy expenditures, activity budgets, and prey harvest of breeding Common Murres. - Stud. Avian Biol. 14, 84-92.

Grunsky, B., 1992. Anwesenheit adulter Trottellummen (Uria aalge) in der Brutkolonie auf Helgoland, Bestandsermittlung und Nahrungsökologie ihrer Junġen. Dipl.Arb., Univ. Bonn, 98 pp.

Leopold, M. F., Wolf, P. A. \& Hüppop, O., 1992. Food of young and colony-attendance of adult Guillemots Uria aalge on Helgoiand. - Helgoländer Meeresunters. 46, 237-249.

Tasker, M. L., Jones, P. H., Dixon, T. \& Blake, B. F., 1984. Counting seabirds from ships: a review of methods employed and a suggestion for a standardized approach. - Auk 101, 567-577. 